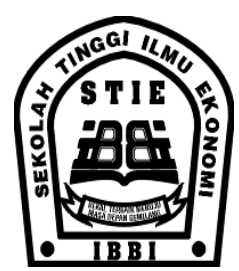

ISSN 1858-3199

JURNAL

MANAJEMEN BISNIS

STIE IBBI

\title{
PENGARUH KOMPENSASI FINANSIAL, DISIPLIN KERJA DAN KEPUASAN KERJA TERHADAP KINERJA KARYAWAN PADA PT. ABIDIN PALMITA BROSS MEDAN
}

\author{
Drs. Junaidi Hasan, MM${ }^{1}$, Fadhlan Thariq ${ }^{2}$ \\ ${ }^{1,2}$ Program Studi Manajemen STIE IBBI \\ Email: junaidihasan1961@ yahoo.com \\ Email : fadhlanthariq05@gmail.com
}

Tujuan penelitian yang dilakukan pada PT Abidin Palmita Bross Medan adalah mengetahui pengaruh Kompensasi Finansial, Disiplin Kerja dan Kepuasan Kerja secara parsial dan secara simultan terhadap kinerja karyawan pada PT. Abidin Palmita Bross Medan.

Metode penelitian yang digunakan adalah metode deskriptif kuantitatif untuk mengetahui pengaruh Kompensasi Finansial, Disiplin Kerja dan Kepuasan Kerja terhadap kinerja karyawan yang dilakukan melalui pengumpulan data menggunakan kuesioner dan analisis data kuantitatif serta pengujian statistik. Teknik analisis data yang digunakan adalah uji regresi linier berganda, uji t dan uji $\mathrm{F}$, serta koefisien determinasi.

Hasil penelitian dari uji regresi linier berganda diperoleh $Y=0,815+0,557 X_{1}+-0,112 X_{2}+0,221 X_{3}$. Hasil uji t membuktikan bahwa secara parsial variabel Kompensasi Finansial, Disiplin Kerja dan variabel Kepuasan Kerja berpengaruh Positif dan signifikan terhadap kinerja karyawan pada PT Abidin Palmita Bross Medan. Hasil uji F menunjukkan bahwa Kompensasi Finansial, Disiplin Kerja dan Kepuasan Kerja secara simultan berpengaruh terhadap kinerja karyawan. Koefisien determinasi (adjusted R square ) yang diperoleh sebesar 0,975 yang menunjukkan bahwa 2,5\% kinerja karyawan dapat dijelaskan oleh variabel Kompensasi Finansial, Disiplin Kerja dan Kepuasan Kerja.

\section{Kata Kunci: Kompensasi Finansial, Disiplin Kerja dan Kepuasan Kerja dan Kinerja Karyawan.}




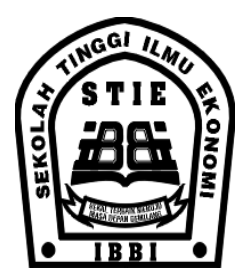

1. PENDAHULUAN

Sumber daya manusia merupakan tokoh sentral dalam organisasi maupun perusahaan. Agar aktivitas manajemen berjalan dengan baik, perusahaan harus memiliki karyawan yang berpengetahuan dan berketerampilan tinggi serta usaha untuk mengelola perusahaan semaksimal mungkin sehingga kinerja karyawan akan meningkat. Tingkat keberhasilan suatu perusahaan dapat dilihat dari kinerjanya. Dengan adanya kinerja karyawan yang tinggi di dalam perusahaan, maka tujuan perusahaan dapat tercapai secara maksimal dan beban perusahaan dapat terselesaikan secara efektif dan efisien sehingga masalah perusahaan satu persatu dapat teratasi.

PT Abidin Palmita Bross Medan merupakan perusahaan yang bergerak di bidang penjualan kelapa sawit. Tanaman kelapa sawit merupakan salah satu perkebunan di Indonesia yang memiliki masa depan cukup cerah. Kelapa sawit bukanlah tanaman asli Indonesia namun kedatangan kelapa sawit ke Indonesia malah menambah komoditas ekspor di Indonesia. Minyak olahan kelapa sawit menjadi komoditas ekspor yang handal di Indonesia, pangsa pasar di dalam negeri cukup besar dan pasaran ekspornya senantiasa terbuka.

Kinerja (performance) adalah hasil pekerjaan yang dicapai seseorang berdasarkan persyaratanpersyaratan pekerjaan (job requirement). Suatu pekerjaan mempunyai persyaratan tertentu untuk dapat dilakukan dalam mencapai tujuan yang disebut juga sebagai standard pekerjaan (job standard). Proses yang dilakukan organisasi untuk mengevaluasi atau menilai keberhasilan karyawan dalam melaksanakan tugasnya. Sistem manajemen kinerja yang baik dapat mengukur dan mengevaluasi suatu pekerjaan di perusahaan. Perusahaan juga perlu menerapkan sistem manajemen kinerja yang baik agar karyawan merasa adil dan nyaman melaksanakan pekerjaannya.

Penilaian kinerja dikatakan penting mengingat melalui penilaian kinerja dapat diketahui seberapa tepat karyawan telah menjalankan pekerjaannya. Ketepatan karyawan dalam menjalankan pekerjaannya akan saat berpengaruh terhadap

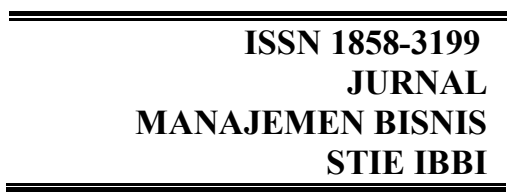

pencapaian kinerja perusahaan secara keseluruhan. Selain itu, hasil penilaian kinerja karyawan akan memberikan manfaat penting dalam proses perkembangan karyawan".

Kinerja karyawan dengan hasil kerja, baik secara kualitas maupun kuantitas yang dicapai oleh sumber daya manusia sesuai dengan peran dan tanggung jawab yang dibebankan kepada karyawan untuk mencapai tujuan organisasi. Kinerja karyawan penting sebagai salah satu alat peningkatan keberhasilan perusahaan dalam menjalankan usaha. Semakin meningkat kinerja karyawan, maka semakin cepat perusahaan mencapai keberhasilan dalam menjalankan usaha dan sebaliknya. Kinerja karyawan dapat ditingkatkan jika didukung oleh pemberian kompensasi finansial yang memadai, disiplin kerja yang baik dan kepuasan kerja yang efektif.

Kompensasi finansial merupakan kompensasi yang diwujudkan perusahaan dengan pemberian sejumlah gaji karyawan. Perusahaan memberikan kompensasi finansial kepada karyawan untuk merangsang karyawan agar dapat bekerja lebih baik dan optimal. Jika pemberian kompensasi finansial memadai, maka karyawan akan termotivasi untuk bekerja lebih baik dan optimal sehingga dapat meningkatkan kinerjanya".

Adapun permasalahan yang berhubungan dengan kompensasi finansial adalah karyawan merasa tidak adil dalam pemberian kompensasi finansial yang berupa gaji, insentif dan bonus belum sesuai yang di terima oleh karyawan dan tidak seimbang dengan pekerjaan yang mereka kerjakan. Hal ini disebabkan rendahnya kinerja karyawan sehingga karyawan tidak mampu bekerja dengan baik, sesuai dengan tugas yang diberikan perusahaan.

Disiplin merupakan suatu sikap karyawan yang mentaati peraturan, tata tertib, norma-norma yang berlaku, baik tertulis maupun yang tidak tertulis. Disiplin sangat penting untuk mendukung pertumbuhan perusahaan dan digunakan untuk memotivasi karyawan agar dapat mendisiplinkan diri dalam melaksanakan pekerjaan, baik secara perorangan maupun kelompok". 


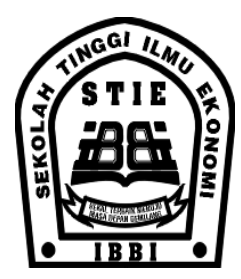

Dalam hal disiplin kerja terdapat permasalahan mengenai teladananya pemimpin di PT Abidin Palmita Bross Medan, dalam menentukan disiplin karyawan maka pimpinan dijadikan teladan dan panutan oleh para bawahannya. Pimpinan harus memberi contoh yang baik, berdisiplin baik, jujur, adil serta sesuai kata dengan perbuatan. Sehingga kurangnya ketegasan pemimpin maka kinerja karyawan menurun mengakibatkan karyawan tidak taat menyelesaikan tugas yang telah diberikan perusahaan. Dan karyawan yang tidak disiplin tersebut akan mendapatkan sanksi hukum yang telah ditentukan perusahaan tersebut. Kurangnya keadilan terhadap karyawan atas limpahan pekerjaan yang diberikan perusahaan, adanya perbedaan antara karyawan satu dengan karyawan lainnya. Sehingga hubungan antara karyawan kurang baik dan kurang harmonis terhadap karyawan tersebut.

Kepuasan kerja karyawan merupakan sikap umum karyawan terhadap berbagai aspek maupun pekerjaan yang dijalankannya. Jika seseorang karyawan mendapatkan kepuasan kerja yang rendah maka karyawan tersebut akan menunjukkan kinerja yang tidak baik bagi perusahaan, dan sebaliknya apabila karyawan mendapatkan kepuasan kerja yang tinggi pada pekerjaannya maka karyawan tersebut akan memiliki kinerja karyawan yang baik, sehingga dapat dikatakan bahwa kepuasan kerja merupakan kunci pendorong moral, kedisiplinan dan prestasi kerja karyawan dalam mendukung terwujudnya tujuan perusahaan".

Masalah yang berhubungan dengan kepuasan kerja adalah prestasi kerja karyawan pada PT Abidin Palmita Bross Medan, yang tidak di akui oleh perusahaan. Karena karyawan merasa pekerjaan yang diberikan pimpinan kepada mereka terlalu berat, pertumbuhan yang kurang memadai untuk melakukan pekerjaan, dan jaminan kesehatan berupa BPJS belum terealisasi sehingga karyawan tidak sungguh-sungguh dalam melakukan pekerjaan mereka dan hal ini berdampak pada menurunnya kinerja perusahaan tersebut. Sehingga karyawan kurang menyenangi pekerjaannya itu sendiri, maka prestasi kerja karyawan terus menerus turun. Dan akan menyebabkan kurangnya kemajuan dalam menyelesaikan tugas sehari-hari yang diberikan perusahaan.

\section{KAJIAN LITERATUR \\ Kompensasi Finansial}

Bangun (2012:225) mengemukakan

"Kompensasi finansial adalah bentuk kompensasi yang dibayarkan kepada karyawan dalam bentuk uang atau jasa yang mereka sumbangkan pada pekerjaanya".

Suntoyo (2013:31) mengemukakan bahwa "Kompensasi finansial adalah sesuatu yang diterima oleh karyawan dalam bentuk seperti gaji, upah, bonus, premi, tunjangan hari raya, tunjangan hari tua, pengobatan atau jaminan kesehatan, asuransi, dan lain-lain yang sejenis yang dibayarkan oleh organisasi".

Menurut Samudra (2014), mengemukakan "Kompensasi finansial merupakan kompensasi yang diwujudkan perusahaan dengan pemberian sejumlah gaji karyawan. Perusahaan memberikan kompensasi finansial kepada karyawan untuk merangsang karyawan agar dapat bekerja lebih baik dan optimal. Jika pemberian kompensasi finansial memadai, maka karyawan akan termotivasi untuk bekerja lebih baik dan optimal sehingga dapat meningkatkan kinerjanya".

\section{Disiplin Kerja}

Mangkunegara (2013:129) mengemu-kakan bahwa "Disiplin kerja dapat diartikan sebagai pelaksanaan manajemen untuk memperteguh pedoman-pedoman organisasi".

Darmawan (2013:41) mengemukakan "Disiplin diartikan sebagai suatu sikap, tingkah laku, dan perbuatan yang sesuai peraturan dari organisasi dalam bentuk tertulis maupun tidak".

Hasibuan (2012 :193) mengemukakan "Kedisiplinan kerja merupakan kesadaran dan kesediaan seseorang yang menaati semua peraturan perusahaan dan norma-norma social yang berlaku".

\section{Kepuasan Kerja}

Menurut Hasibuan (2010:202) mengemukakan "kepuasan kerja adalah sikap emosional yang 


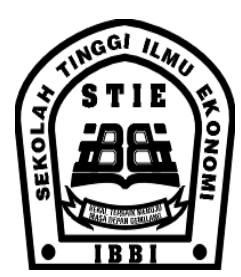

menyenangkan dan mencintai pekerjaanya. Sikap ini dicerminkan oleh moral kerja, kedisiplinan dan prestasi kerja. Kepuasan ini dinikmati dalam pekerjaan, luar pekerjaan dan kombinasi keduanya".

Menurut Robbins (2011:62) "kepuasan kerja merupakan penilaian, perasaan atau sikap seseorang atau karyawan terhadap pekerjaanya dan berhubungan dengan lingkungan kerja, jenis pekerjaan, kompetensi dan hubungan antara teman kerja serta hubungan sosial ditempat kerja dan sebagianya".

Menurut Dadang (2013:15) "kepuasan kerja adalah keadaan emosional yang menyenangkan atau tidak menyenangkan terhadap pekerjaan, kepuasan kerja mencerminkan perasaan seseorang terhadap pekerjaannya".

\section{Kinerja}

Hasibuan (2012:94) mengemukakan "Kinerja yaitu suatu hasil kerja yang dicapai karyawan dalam melaksanakan tugas-tugas yang dibebankan kepada yang didasarkan atas kecakapan, pengalaman, dan kesungguhan serta waktu".

Wibowo (2013:7) "kinerja atau prestasi kerja adalah hasil pekerjaan yang mempunyai hubungan kuat dengan tujuan strategis organisasi, kepuasan konsumen, dan memberikan kontribusi pada ekonomi”.

Prawirosentono dalam Sinambela (2012:5) mengemukakan bahwa "kinerja adalah hasil kerja yang dapat dicapai oleh seseorang atau sekelompok orang dalam suatu organisasi, sesuai dengan wewenang dan tanggung jawab masing-masing, dalam rangka upaya mencapai tujuan organisasi bersangkutan secara legal, tidak melanggar hokum dan sesuai dengan moral maupun etika".

\section{METODOLOGI PENELITIAN}

Metode pengambilan sampel dengan menggunakan teknik sampling jenuh, dimana sampel ini digunakan apabila semua anggota populasi digunakan sebagai sampel, yang didasarkan atas adanya tujuan tertentu dan tetap berhubungan dengan permasalahan penelitian.

Teknik analisis data yang digunakan adalah regresi linier berganda setelah memenuhi asumsi
ISSN 1858-3199

JURNAL

MANAJEMEN BISNIS

STIE IBBI

klasik menyangkut normalitas, multikolinieritas, dan heteroskedastisitas . Penarikan kesimpulan atas hiipotesis dilakukan dengan cara uji $t$ dan uji f pada level signifikansi $5 \%$.

\section{HASIL DAN PEMBAHASAN \\ Uji Regresi Linier Berganda}

Model persamaan regresi linier berganda sebagai berikut :

$$
\mathrm{Y}=\mathbf{0 , 8 1 5}+\mathbf{0 , 5 5 7}+\mathbf{0 , 1 2 2}+\mathbf{0 , 2 2 1}+\mathrm{e}
$$

\section{a. Konstanta $(\mathbf{a})=\mathbf{0 , 8 1 5}$}

Yang artinya jika variabel komunikasi, stress kerja dan fasilitas kerja dianggap tetap maka produktivitas karyawan setara dengan 0,815.

b. Koefisien Kompensasi Finansial (b1) $=\mathbf{0 , 5 5 7}$

Artinya jika terjadi peningkatan variabel kompensasi finansial sebesar satu-satuan, disiplin kerja dan kepuasan kerja, dianggap tetap. Maka kinerja karyawan akan mengalami peningkatan sebesar 0,557.

c. Koefisien Disiplin Kerja $(\mathbf{b 2})=\mathbf{0 , 1 2 2}$

Artinya jika terjadi peningkatan variabel disiplin kerja sebsar satu-satuan, kompensasi finansial dan kepuasan kerja, dianggap tetap. Maka kinerja karyawan akan mengalami peningkatan sebesar 0,122.

d. Koefisien Kepuasan Kerja (b3) $=0,221$

Artinya jika terjadi peningkatan variabel kepuasan kerja sebesar satu-satuan, kompensasi finansial dan disiplin kerja, dianggap tetap. Maka kinerja karyawan akan mengalami peningkatan sebesar 0,221.

\section{Hasil Uji t}

Pengujian parsial (Uji t) dilakukan bertujuan untuk mengetahui ada tidaknya berpengaruh setiap variabel independen terhadap variabel dependen secara parsial.

Hasil uji-t dapat disimpulkan sebagai berikut :

a. Nilai t-hitung kompensasi finansial 9,521 sedangkan t-tabel $=2,007$ berarti f-hitung $>\mathrm{f}$ tabel tingkat signifikan $0,000>0,05$ sehingga dapat disimpulkan bahwa variabel kompensasi 


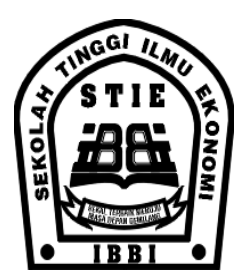

finansial berpengaruh signifikan terhadap kinerja karyawan. Hal ini tersebut membuktikan bahwa $\mathrm{H} 1$ diterima.

b. Nilai t-hitung disiplin kerja 2,781 sedangkan ttabel $=2,007$ berarti f-hitung >f-tabel tingkat signifikan $0,008>0,05$ sehingga dapat disimpulkan bahwa variabel disiplin kerja berpengaruh signifikan terhadap kinerja karyawan. Hal ini tersebut membuktikan bahwa $\mathrm{H} 2$ diterima.

c. Nilai t-hitung kepuasan kerja 3,117 sedangkan t-tabel $=2,007$ berarti f-hitung $>\mathrm{f}$-tabel tingkat signifikan $0,003>0,05$ sehingga dapat disimpulkan bahwa variabel kepuasan kerja berpengaruh signifikan terhadap kinerja karyawan. Hal ini tersebut membuktikan bahwa H3 diterima.

\section{Hasil Uji F}

Uji F pada dasarnya menunjukkan apakah semua variabel bebas yang dimasukkan dalam model mempunyai pengaruh secara bersama-sama terhadap variabel terikat.

Hasilnya dapat diketahui bahwa nilai f-tabel adalah 2,78, maka hasil SPSS ini diperoleh f-hitung sebesar dan jika dilihat dari f-hitung dan f-tabel maka uji simultan ini memenuhi kriteria f-hitung $>\mathrm{f}$ tabel $(689,726>2,78)$ dan nilai signifikan 0,000 lebih kecil dari 0,05, maka dapat disimpulkan bahwa variabel kompensasi finansial, disiplin kerja dan kepuasan kerja berpengaruh positif dan signifikan terhadap kinerja karyawan.

\section{Koefisien Determinasi (R-Square)}

Pengujian koefisien determinasi (R2) digunakan untuk mengukur pengaruh variabel bebas terhadap variabel terikat. Sebaliknya jika R2 semakin kecil (mendekati nol) maka dapat dikatakan bahwa pengaruh variabel bebas terhadap variabel terikat semakin kecil.

Berdasarkan hasil pengujian dapat diketahui nilai Adjusted R square (angka korelasi atau $\mathrm{r}$ yang dikuadratkan) sebesar 0,975. Adjusted $\mathrm{R}$ square disebut juga dengan koefisien determinasi. Besarnya nilai koefisien determinasi 0,975 atau sama dengan $97,5 \%$ yang artinya $97,5 \%$ perubahan kinerja
ISSN 1858-3199

JURNAL

MANAJEMEN BISNIS

STIE IBBI

karyawan yang dapat dijelaskan oleh variabel kompensasi finansial, disiplin kerja, dan kepuasan kerja sedangkan sisanya sebesar 2,5\% dapat di jelaskan oleh faktor-faktor lain yang tidak dimasukkan dalam penelitian ini seperti Lingkungan Kerja, Kepemimpinan dan Fasilitas Kerja.

\section{PEMBAHASAN}

\section{Pengaruh Kompensasi Finansial Terhadap Kinerja Karyawan}

Secara Parsial variabel kompensasi finansial (X1) memiliki pengaruh positif dan signifikan terhadap kinerja karyawan, dimana hasil dari penelitian diperoleh bahwa nilai yaitu 9,521 >2,007, dan taraf signifikan t-hitung $<\mathrm{t}$-tabel yaitu $0,000<0,05$. Hal ini menunjukkan bahwa parsial dan signifikan kompensasi finansial berpengaruh terhadap kinerja karyawan. Hasil tersebut sejalan dengan penelitian Ilham Thaief (2015) menjelaskan bahwa kompensasi finansial berpengaruh positif terhadap kinerja karyawan.

\section{Pengaruh Disiplin Kerja Terhadap Kinerja Karyawan}

Secara Parsial variabel disiplin kerja (X2) memiliki pengaruh positif dan signifikan terhadap kinerja karyawan, dimana hasil dari penelitian diperoleh bahwa nilai yaitu 2,781 $>2,007$, dan taraf signifikan t-hitung $<$ t-tabel yaitu $0,008<0,05$. Hal ini menunjukkan bahwa secara parsial dan signifikan disiplin kerja berpengaruh terhadap kinerja karyawan. Hasil tersebut sejalan dengan penelitian Rista Eka Rachim, Febiningtyas (2014) yang menjelaskan bahwa disiplin kerja berpengaruh positif terhadap kinerja karyawan.

\section{Pengaruh Kepuasan Kerja Terhadap Kinerja Karyawan}

Secara Parsial variabel kepuasan kerja (X3) memiliki pengaruh positif dan signifikan terhadap kinerja karyawan,

1. Berdasarkan pengujian secara parsial bahwa terdapat pengaruh yang positif dan signifikan variabel kompensasi finansial terhadap kinerja karyawan pada PT Abidin Palmita Bross Medan. 


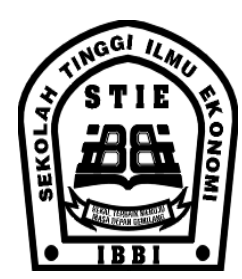

2. Berdasarkan pengujian secara parsial bahwa terdapat pengaruh yang positif dan signifikan variabel disiplin kerja terhadap kinerja karyawan pada PT Abidin Palmita Bross Medan.

3. Berdasarkan pengujian secara parsial bahwa terdapat pengaruh yang positif dan signifikan variabel kepuasan kerja terhadap kinerja karyawan pada PT Abidin Palmita Bross Medan.

4. Berdasarkan pengujian secara simultan terdapat pengaruh yang positif dan signifikan variabel kompensasi finansial, disiplin kerja, dan kepuasan kerja terhadap kinerja karyawan pada PT Abidin Palmita Bross Medan.

5. Nilai koefisien determinasi yang dapat dilihat dari nilai Adjusted R Square sebesar 0,975 artinya variabel independen yang terdiri dari kompensasi finansial, disiplin kerja, dan kepuasan kerja dapat menjelaskan kinerja karyawan sebesar $97,5 \%$ dan sisanya $2,5 \%$ dijelaskan variabel lainnya yang tidak dimasukkan dalam model penelitian seperti gaji, kepemimpinan, dan fasilitas kerja.

Berdasarkan hasil dan kesimpulan dalam penelitian ini, penulis memberikan beberapa saran atau masukan sebagai bahan pertimbangan perusahaan sebagai berikut:

1. Manajemen kompensasi pada perusahaan harus lebih diperhatikan lagi, sehingga semua karyawan dapat bekerja dengan sesuai standard yang telah ditentukan perusahaan. Kompensasi finansial sangat bermanfaat bagi perkembangan perusahaan dan keuntungannya para karyawan akan bekerja lebih giat lagi. Kompensasi sangatlah penting bagi perusahaan, maka dari itu kompensasi harus sangat diperhatikan oleh perusahaan. Karena jikalau masalah kompensasi tidak berjalan dengan baik perusahaan tidak akan berkembang dan akan menurunkan kinerja karyawan maka dari itu perusahaan harus memperhatikan kompensasi karyawan secara baik.

2. Disiplin kerja merupakan tindakan manajemen untuk mendorong agar karyawan dapat memenuhi berbagai ketentuan dan peraturan

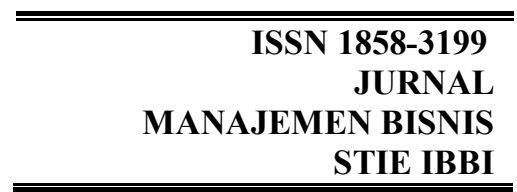

yang berlaku dalam perusahaan. Disiplin kerja meningkat menjadi kebiasaan berpikir baik, positif, bermakna dan memandang jauh ke depan. Disiplin bukan hanya soal mengikuti dan menaati peraturan, melainkan sudah meningkat menjadi disiplin berpikir yang mengatur dan mempengaruhi aspek kinerja karyawan. Disiplin itu sangat diperlukan sebagai tolak ukur mampu atau tidaknya seseorang dalam menaati aturan bagi stabilitas perusahaan.

3. Kepuasan kerja adalah seperangkat perasaan tentang menyenangkan atau tidaknya pekerjaan karyawan. Kepuasan kerja adalah bagian dari kepuasan hidup sifat lingkungan kerja di dalam perusahaan ataupun di luar perusahaan. Demikian halnya karena pekerjaan merupakan bagian penting kehidupan. Kepuasan kerja bagaimana perusahaan menghargai pekerjaan karyawannya dan membuat karyawan merasa nyaman dalam bekerja sehingga dapat meningkatkan kinerja karyawan dalam perusahaan. dimana hasil dari penelitian diperoleh bahwa nilai yaitu 3,117>2,007, dan taraf signifikan t-hitung $<\mathrm{t}$-tabel yaitu $0,003<0,05$. Hal ini menunjukkan bahwa secara parsial dan signifikan kepuasan kerja berpengaruh terhadap kinerja karyawan. Hasil tersebut sejalan dengan penelitian Wanda Febriyana (2015) yang menjelaskan bahwa kepuasan kerja berpengaruh positif terhadap kinerja karyawan.

Hasil hipotesis pada uji F (simultan) juga membuktikan bahwa secara simultan kompensasi finansial, disiplin kerja, dan kepuasan kerja secara bersama-sama memiliki pengaruh terhadap kinerja karyawan dapat dilihat dari nilai F-hitung sebesar $689,726>$ F-tabel sebesar 2,78. Hal ini sesuai dengan hasil penelitian Samudra, Rahardjo, dan Mukzam (2014) yang menyatakan bahwa kompensasi finansial, disiplin kerja, dan kepuasan kerja secara simultan dan parsial berpengaruh signifikan terhadap kinerja karyawan.

Kompensasi finansial, disiplin kerja, dan kepuasan kerja sama-sama mempunyai hubungan dan pengaruh positif terhadap kinerja karyawan dengan Nilai Adjusted R square sebesar 97,5\% 


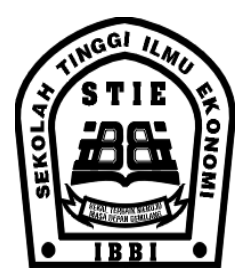

sedangkan sisanya sebesar 2,5\% dapat dijelaskan oleh faktor-faktor lain yang tidak dimasukkan dalam penelitian ini. Selain itu, tanda positif pada angka 0,975 menunjukkan adanya arah yang sama dari kedua variabel tersebut, artinya semakin tinggi tingkat kinerja karyawan pada PT Abidin Palmita Bross Medan.

\section{KESIMPULAN}

1. Berdasarkan pengujian secara parsial bahwa terdapat pengaruh yang positif dan signifikan variabel kompensasi finansial terhadap kinerja karyawan pada PT Abidin Palmita Bross Medan.

2. Berdasarkan pengujian secara parsial bahwa terdapat pengaruh yang positif dan signifikan variabel disiplin kerja terhadap kinerja karyawan pada PT Abidin Palmita Bross Medan.

3. Berdasarkan pengujian secara parsial bahwa terdapat pengaruh yang positif dan signifikan variabel kepuasan kerja terhadap kinerja karyawan pada PT Abidin Palmita Bross Medan.

4. Berdasarkan pengujian secara simultan terdapat pengaruh yang positif dan signifikan variabel kompensasi finansial, disiplin kerja, dan kepuasan kerja terhadap kinerja karyawan pada PT Abidin Palmita Bross Medan.

5. Nilai koefisien determinasi yang dapat dilihat dari nilai Adjusted $\mathrm{R}$ Square sebesar 0,975 artinya variabel independen yang terdiri dari kompensasi finansial, disiplin kerja, dan kepuasan kerja dapat menjelaskan kinerja karyawan sebesar 97,5\% dan sisanya 2,5\% dijelaskan variabel lainnya yang tidak dimasukkan dalam model penelitian seperti gaji, kepemimpinan, dan fasilitas kerja.

\section{REFERENSI}

Amstrong, 2010. Manajemen Sumber Daya Manusia. Yogyakarta

Bangun, Wilson. 2012. Manajemen Sumber Daya Manusia. Jakarta: Erlangga. Darmawan, Didit. 2013. Prinsip-Prinsip Perilaku Organisasi. Surabaya: Pena Semesta

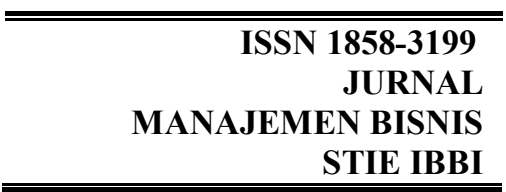

Dadang. 2013. E-Business \& E-Commerce. Yogyakarta: Penerbit Andi.

EdySutrisno. 2014. Manajemen Sumber Daya Manusia. Cetak Keenam Pranada Media Group, Jakarta

Febiningtyas, Rista Eka Rachim. 2014. The Effect Of Leadership, Motivation, And work Discipline On The Employees' Performance Of Finance Section In The Regional Working Unit In Tulungagung Regency. The Indonesia Accounting Review, Vol. 4 No. 2.

Hasibuan, Malayu S.P. 2013. Manajemen Sumber Daya Manusia, Edisi Revisi. Jakarta: Bumi Aksara.

Kaswan. 2012. Manajemen Sumber Daya Manusia untuk Keunggulan Bersaing Organisasi. Yogyakarta: Graha Ilmu.

Mangkunegara, A.A. Anwar Prabu. 2013. Manajemen Sumber Daya Manusia Perusahaan. Bandung: PT Remaja Rosdakarya.

Mangkunegara, Anwar Prabu. 2010. Manajemen Sumber Daya Manusia Perusahaan. Bandung: Penerbit Rosda.

Mandala, Hartono. 2014. Indikator- indikator kepuasan kerja.

Masoma Javed, Rifat Balouch, Fatima Hasan. 2014. Determinants Of Job Satisfaction and its impact On employee performance and turnover intentions 2014. Vol. 4. No.2

Notoatmodjo, Soekidjo. 2009. Pengembangan Sumber Daya Manusia. Jakarta: Rineka Cipta.

Pusphakumari. 2012. The Impact Of Job Satisfaction on Job Performance of Private Sector in Srilangka. London: Journal Business and Management.

Robbins, Stephen. 2011. Perilaku Organisasi. Jakarta: Penerbit Salemba Empat.

Samudra, Angga Putra, Kusdi Rahardjo, dan M. Djudi Mukzam. 2014. Pengaruh Kompensasi Finansial Terhadap Kinerja (Studi pada Karyawan PT. Bank Jatim Cabang Malang). 


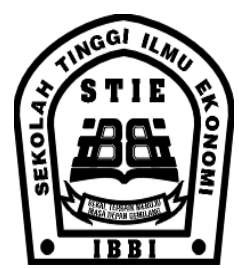

ISSN 1858-3199

Jurnal Administrasi Bisnis (JAB) Volume 7, No. 2 Januari 2014.

Sunyoto, Danang. 2013. Manajemen Sumber Daya Manusia. Jakarta: PT. Buku Seru.

Sutrisno, H. Eddy. 2009. Manajemen Sumber Daya Manusia. Jakarta: Kencana.

Thaief, Ilham. 2015. Effect Of Training, Financial Compensation and work Discipline against Employee Job Performance (Studies in the Office of PT. PLN (Persero) Service Area and Network Malang). Review of European Studies, Vol. 7, No. 11.

Wibowo. 2014. Manajemen Kinerja, Edisi-4. Jakarta: PT. Rajagrafindo Persada.

Yani, H.M. 2012. Manajemen Sumber Daya Manusia. Jakarta: Mitra Wacana Media.

Yusuf. 2014. Pengaruh Kepemimpinan, Komunikasi, Motivasi Kerja, dan Disiplin Terhadap Kinerja Karyawan PT. Komatsu Remanufacturing Asia Plant Sudirma Di Departemen Produksi Balik Papan Jurnal Ilmu Ekonomi \& Manajemen, Vol. 10, No. 1. 